\title{
THE CONCEPT OF QUALITATIVE STUDY OF STUDENTS IN PHYSICAL EDUCATION STUDY PROGRAMME OF THE LITHUANIAN UNIVERSITY OF EDUCATIONAL SCIENCES
}

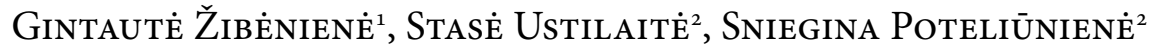 \\ ${ }^{1}$ Mykolas Romeris University, Vilnius, Lithuania \\ ${ }^{2}$ Lithuanian University of Educational Sciences, Vilnius, Lithuania
}

\begin{abstract}
By analyzing European and national documents regulating studies in higher education schools one can see that a student has become an important participant in securing the process of quality of studies. Therefore, it is important to systematically analyze students' attitudes to various aspects connected to quality of studies. The aim of the research was to convey the conception of quality of studies by first and last year students of physical education. The research was carried out in 2013-2014 and 121 first and last year students of Lithuanian University of Educational Sciences participated in it. The following research methods were applied: scientific literature and documents, students' answers to open question: "what are quality studies for you personally?", and quality content analysis. By singling out categories naming of research participants (keyword or phrase) were taken into account as well as study quality exterior assessment by areas according to legal acts of Lithuania. By analyzing conception of quality studies of first and last year students of physical education eight quality categories have been singled out: study outcomes, structure of study programme, study process, favourable study environment, material and methodical resources, lecturers, accessibility of studies and possibility to be employed, prestige institutions and studies.
\end{abstract}

Keywords: students of physical education; quality of studies; concept of quality studies 


\section{INTRODUCTION}

By reviewing the European Union (EU) documents of Bologna process it is seen that a student is an important participant in the process of securing quality of studies. European documents encourage to incorporate students into assessment of study quality in the higher education schools, to systematically investigate their opinion on study quality questions, consider students, social partners and other participants of study quality system presented offers and weigh expedience to consider them as part of improvement of quality of studies [8-12]. Implementing reform of higher education in Lithuania in 1999, a student was acknowledged an important participant in securing system of quality of studies. Therefore, even in national documents a need is indicated for a higher education school to systematically proclaim "...precise quantitative and qualitative information about $\langle\ldots\rangle$ students, graduates and opinion of other concerned parties about quality of studies" [22]. However, improving quality of studies in practice various conceptions of qualitative studies are often encountered when employers criticize some aspects, students others, lecturers and exterior assessors have yet another opinion. El Hassan [13] and Balasooriya et al. [4] notice significance of students' opinion towards research of university studies. The attitude of students towards teaching quality has been analyzed by Allan and Pileičikienè [1] and validated as an important aspect of qualitative studies.

Almadani et al. [2] note that such questions as improving quality of studies is one of the most topical. There has been an increase of scientific articles in scientific literature in the last decade, where quality of studies, questions regarding improvement of quality of studies are discussed and an opinion of students about various study programmes is analyzed. However, it has been noticed that very few of those articles discuss personal conception of quality of studies of students of physical education and not study quality assessment or theoretical conceptions. Bobrova et al. [7] and Baranauskiene et al. [5] analyzed an attitude of physical education students to quality of studies, and they named what, in students' conception, learning is and what it means to learn. Bobrova et al. [6] examined the attitude of physical education students towards the quality of teaching. In Lithuania, there has been researched students' attitude towards lecturing, assessment of students' achievements, possibilities of personal improvement, academic support and organizing of studies, the infrastructure of studies and external connections of higher education institutions, where students of physical education also took part [21]. Kardeliene [15] analyzed academic Library as the Space for the Development of Future Physical Education Professionals' Competence. 
Richards et al. [19] inquired into the heart of the preparation of the teachers of physical education, presented recommendations for the preparation of physical education teachers. Šeščilienè and Rastauskienè [23] analyzed first stage students' of Lithuania physical education academy attitude to quality of lecturing and revealed how students assess process of studies, quality of lecturing, goals of studies, achievements, results and the like. However, it has not been researched how students of physical education understand qualitative studies and it is not clear what conception of qualitative studies they have when they start studying and whether this conception changes during the study period or not. The issue is raised how students' understanding of qualitative studies changes during study period and whether last year students raise higher requirements for quality of studies in comparison to first year students. The subject of this research is first and last year students of physical education of Lithuanian University of Educational Sciences. The object of the research is students' understanding of quality studies. The goal of the research is to convey understanding of quality studies of first and last year students of physical education. The article first and foremost attempts to shortly introduce what conception of quality studies exterior study quality assessors should follow. That is, criteria for quality of studies are introduced. In other essential part of the article, conception of quality studies by physical education students is reviewed.

\section{Criteria of assessment for quality of studies applied for exterior assessment of quality of studies}

The concept of quality is not defined evenly. It is connected to meeting of expectations or by relying on definition of International standardization organization: quality is the summation of features and characteristics of a product or service that provides with a possibility to satisfy defined or anticipatory needs [24]. The conception of quality of studies is ambiguous and changeable. This fluctuation is firstly connected to changeable purposes of higher education, which are conditioned by changing exterior environment of higher education, requirements of mouthpieces for quality of studies, changing needs and expectations of those who study, processes of higher education globalization. As Lithuanian higher education joins the space of European higher education, securing of quality of studies has become not only a national aim, but also of European importance. Westerheijden [24] states that still new definitions of quality in the area of higher education emerge any given moment, so quality in itself is a moving target as it changes when we move towards this moving target, i.e. how we assess quality of 
higher education. According to Milišiūnaite et al. [17], quality of studies is the propriety of conditions provided by higher education establishment for self help development of a person and necessary level for acquirement of qualification by satisfying interior and exterior needs and implied expectations of partakers of higher education at most. The above mentioned authors state that usually the quality of studies is understood as combination of two conceptions: the fitness of purpose of goals pursued by the institution of higher education for the mission of institution and interior as well as exterior expectations and needs of partakers, and likewise propriety of available resources by higher education schools and the propriety of provided conditions and the fitness for purpose to implement the mission and strategic purposes of the institution of higher education [17].

Part 2 of article 40 of the Law of Education and Science of the Republic of Lithuania provides that quality of science (art) activity and studies is insured through inner quality security systems of science and study institutions, exterior assessment and accreditation of exterior study programmes, exterior assessment of scientific activity and exterior assessment and (or) accreditation of science and study institutions [22].

On the basis legal acts of Lithuania, the quality of activities of higher education school is assessed according to these areas: strategic management, studies and lifelong learning, activity of science and (or) art, influence of development of regions and entire country $[3,18,22]$, and quality of new or already implemented studies is conveyed by programme assessment according to these areas: purposes of study programme and results of studies, structure of the programme, personnel, material resources, course of studies, management of the programme. By analyzing results of implemented research we will rely on selected areas for exterior assessment of study programme and separate components of areas that are assessed [22]. We will try to reveal which areas of assessment or their components are connected to conception of qualitative studies by students.

\section{MATERIALS AND METHODS}

One hundred and twenty one students of physical education from Lithuanian University of Educational Sciences participated in the research. Among them, 62 were first year students and 59 last year students $(32$ - 3rd year students, 27 - 4th year students). The scope of the research was a comfortable one, because the chosen students attend lectures; do not have previous experience of studying in other higher educational schools, study programmes 
and who were easy to find at their study places. First year students were surveyed during autumn of 2013 (studying the first three months) and last year students during the February and March of 2014.

Research methods applied: scientific literature and documents, students' answers to open question: "what are quality studies for you personally?", and quality content analysis. Students' conception of qualitative studies was analyzed relying on traditional qualitative content analysis, the text was studied by singling out keywords and phrases and forming them into subcategories and categories. The categories were grouped by attributing them to separate areas of exterior assessment of studies that were singled out according to legal acts of Lithuanian. In pursuit to define how students' concept of qualitative studies changes during the course of studies, absolute rates of mentioned statements by students were computed.

Ethics of the research: the research was performed by following principle of voluntarism, in the environment of students' studies and at the time that was comfortable for them. An agreement of the researched was also acquired, the permission of study programme leaders. There was a possibility given not to participate in the research.

\section{RESULTS}

\section{Conception of qualitative studies by students of physical training}

Having performed analysis of informants to an open ended question: "what are quality studies for you personally?" eight quality categories have been singled out: study outcomes, structure of study programme, study process, favourable study environment, material and methodical resources, lecturers, accessibility of studies and possibility to be employed, prestige institutions and studies (Table 1).

It became clear that students mostly recognize and name qualitative study process, study results, importance of lecturers, but the structure of studies, educational environment, material and methodical resources, accessibility of studies, possibility to get employed are mentioned only by some students. 
Table 1. Categories and subcategories (absolute rates) characterizing the concept of quality of studies by physical education students

\begin{tabular}{|c|c|c|c|}
\hline Category & Subcategory & $\begin{array}{l}\text { 1st year } \\
\text { studies }\end{array}$ & $\begin{array}{l}\text { 3rd-4th } \\
\text { year } \\
\text { studies }\end{array}$ \\
\hline \multirow{5}{*}{$\begin{array}{l}\text { Outcomes } \\
\text { of studies (46) }\end{array}$} & Acquired knowledge (26) & 13 & 15 \\
\hline & A competent specialist prepared (15) & 7 & 8 \\
\hline & Preparation for life (2) & 1 & 1 \\
\hline & Acquired knowledge and skills (1) & 1 & \\
\hline & Acquired skills (1) & 1 & \\
\hline \multirow{8}{*}{$\begin{array}{l}\text { Process } \\
\text { of studies (54) }\end{array}$} & Clear lecturing (10) & 9 & 1 \\
\hline & Interesting lecturing (3) & 3 & \\
\hline & Qualitative lecturing (2) & 1 & 1 \\
\hline & $\begin{array}{l}\text { Naming of attributes of qualitative study } \\
\text { process (20) }\end{array}$ & 12 & 8 \\
\hline & Practical teaching dominates (10) & 3 & 7 \\
\hline & $\begin{array}{l}\text { Experience, knowledge, skills are ac- } \\
\text { quired not in "university environment" (6) }\end{array}$ & 6 & \\
\hline & $\begin{array}{l}\text { Correlation between theory and } \\
\text { practice (1) }\end{array}$ & 1 & \\
\hline & Appreciation of personal achievement (2) & 1 & 1 \\
\hline \multirow[t]{5}{*}{ Lecturers (27) } & Competent (15) & 7 & 8 \\
\hline & Good (5) & 4 & 1 \\
\hline & $\begin{array}{l}\text { Demonstrating personal traits that are } \\
\text { important for an educator ( } 3 \text { ) }\end{array}$ & 2 & 1 \\
\hline & Having professional experience (3) & 1 & 2 \\
\hline & Having professional acclaim (1) & 1 & \\
\hline \multirow[t]{2}{*}{$\begin{array}{l}\text { Study programme } \\
\text { structure (9) }\end{array}$} & $\begin{array}{l}\text { Subjects of studies can be applied at } \\
\text { work (3) }\end{array}$ & & 3 \\
\hline & $\begin{array}{l}\text { Subjects of study prepared } \\
\text { for competent specialist (6) }\end{array}$ & 3 & 3 \\
\hline \multirow{3}{*}{$\begin{array}{l}\text { Material and } \\
\text { methodical } \\
\text { resources (10) }\end{array}$} & Premises (5) & 5 & \\
\hline & Modern teaching base ( 3 ) & 1 & 2 \\
\hline & Methodical material (2) & 2 & \\
\hline
\end{tabular}




\begin{tabular}{llcc}
\hline Category & Subcategory & $\begin{array}{c}\text { 1st year } \\
\text { studies }\end{array}$ & $\begin{array}{c}\text { 3rd-4th } \\
\text { year } \\
\text { studies }\end{array}$ \\
\hline $\begin{array}{l}\text { Favorable } \\
\text { educational } \\
\text { environment (9) }\end{array}$ & $\begin{array}{l}\text { Psychologically comfortable } \\
\text { environment (5) }\end{array}$ & 3 & 2 \\
\cline { 2 - 4 } & Favorable conditions for studying (4) & 3 & 1 \\
\hline $\begin{array}{l}\text { Accessibility } \\
\text { of studies and } \\
\text { possibility to get } \\
\text { employed (8) }\end{array}$ & Personal interest of student (4) & 3 & 1 \\
\cline { 2 - 4 } & Inexpensive studies (2) & 1 & 1 \\
\cline { 2 - 4 } & Free studies (1) & 1 & 1 \\
\hline $\begin{array}{llll}\text { Prestigeous } \\
\text { institutions and } \\
\text { studies (5) }\end{array}$ & Markibility to get employed after studies (1) & 2 & 2 \\
\cline { 2 - 4 } & Good education (2) & 1 & \\
\cline { 2 - 4 } & Famous higher education school (1) & & 1 \\
\hline
\end{tabular}

It became clear that students mostly recognize and name qualitative study process, study results, importance of lecturers, but the structure of studies, educational environment, material and methodical resources, accessibility of studies, possibility to get employed are mentioned only by some students.

Future teachers of physical education do not associate the management of study programme or other aspects mentioned in the legal acts of Lithuania with quality of studies, but name new aspects, i.e. the popularity of an institution and studies, and prestige. There have not been noticed essential differences between first and final year students of physical education. The notices of the first year students are often connected to these three areas/categories that are important for qualitative studies: the process of studies (45), outcomes of studies (22), lecturers (15), whereas the notices of $3 \mathrm{rd}$ and 4 th year students are connected with results of studies (24), process of studies (17) and with lecturers (12) (Table 1).

\section{Conception of qualitative studies by students of physical education in connection to the outcomes of studies}

The category of outcomes of studies is related to acquired knowledge, skills and their application in practice, preparation for competent professional activity and life. However, they do not recognize, not use such concepts as study outcomes (Table 2). 
Table 2. Subcategories and supporting statements defining the category of "study outcomes" in the concept of qualitative studies

\begin{tabular}{|c|c|c|c|}
\hline \multirow[t]{2}{*}{ Category } & \multirow[t]{2}{*}{ Subcategory } & \multicolumn{2}{|c|}{ Supporting statements } \\
\hline & & I course & III-IV courses \\
\hline \multirow[t]{5}{*}{$\begin{array}{l}\text { Study } \\
\text { outcomes }\end{array}$} & $\begin{array}{l}\text { Acquired } \\
\text { knowledge } \\
\text { and skills }\end{array}$ & $\begin{array}{l}\text { "acquired topical } \\
\text { knowledge and skills } \\
\text { that are applicable in } \\
\text { practice" }\end{array}$ & \\
\hline & $\begin{array}{l}\text { Acquired } \\
\text { knowledge }\end{array}$ & $\begin{array}{l}\text { "knowledge necessary } \\
\text { for speciality", } \\
\text { "necessary } \\
\text { knowledge" } \\
\text { "comprehensive } \\
\text { knowledge", } \\
\text { "a lot of knowledge", } \\
\text { "knowledge applicable } \\
\text { at work", "knowledge } \\
\text { applicable in the } \\
\text { future" }\end{array}$ & $\begin{array}{l}\text { "a lot of knowledge", "would } \\
\text { acquire knowledge", "nec- } \\
\text { essary information of the } \\
\text { future", "a lot of knowledge", } \\
\text { "can take out a huge baggage } \\
\text { of knowledge", "can be ap- } \\
\text { plied in practice", "can be ap- } \\
\text { plied at work", "to give results } \\
\text { in practice", "applicable in } \\
\text { practice", "proper knowledge", } \\
\text { "innovative", "appropriate for } \\
\text { tomorrow too" }\end{array}$ \\
\hline & $\begin{array}{l}\text { Acquired } \\
\text { abilities }\end{array}$ & "acquired skills" & \\
\hline & $\begin{array}{l}\text { Prepared } \\
\text { for life }\end{array}$ & $\begin{array}{l}\text { "you acquire life expe- } \\
\text { rience" }\end{array}$ & "skills necessary in life" \\
\hline & $\begin{array}{l}\text { Competent } \\
\text { specialist } \\
\text { prepared }\end{array}$ & $\begin{array}{l}\text { "a good specialist } \\
\text { is prepared", "good } \\
\text { preparation for future } \\
\text { work", "in order that } \\
\text { you would be able to } \\
\text { work successfully in } \\
\text { your area" }\end{array}$ & $\begin{array}{l}\text { "prepares a specialist well", } \\
\text { "a good specialist", "you } \\
\text { become a specialist in your } \\
\text { area", "after finishing I need } \\
\text { to feel strong", "so that going } \\
\text { to practice/work we would be } \\
\text { absolutely ready" }\end{array}$ \\
\hline
\end{tabular}

One can notice that students do not talk about values which are a composing part of competence. Students mostly stress knowledge (27), its' relevance and adaptability in practice ("knowledge applicable at work", "knowledge applicable in the future", "relevant knowledge", "innovative", "relevant for tomorrow"). The students identify qualitative studies with the preparation of a competent specialist ("a good specialist is prepared", "well prepared for future work", "prepares a specialist well", "a good specialist", "you become a specialist in your area"). Two students associate qualitative studies with the preparation for life when "you get life experience" and "necessary skills for life". So, some students 
already understand the concept of higher education - importance to train an erudite, an intellectual.

One can envisage that students understand the needs of society and labor market as well as professional requirements for an educator's job.

\section{The concept of qualitative studies by students of physical education in connection to study process}

Looking deeper at the concept of qualitative studies by students of physical education it became clear that most informants (62) associate it with study process. By analyzing students' answers these subcategories clearly diverged - clear lecturing (10), interesting lecturing (3) (Table 3).

Table 3. Subcategories and supporting statements defining category of "study process" in the concept of qualitative studies

\begin{tabular}{|c|c|c|c|}
\hline \multirow[t]{2}{*}{ Category } & \multirow[t]{2}{*}{ Subcategory } & \multicolumn{2}{|c|}{ Supporting statements } \\
\hline & & I course & III-IV courses \\
\hline \multirow[t]{5}{*}{$\begin{array}{l}\text { Study } \\
\text { process }\end{array}$} & Clear lecturing & $\begin{array}{l}\text { "material is clearly and } \\
\text { precisely presented", "explains } \\
\text { clearly", "knows how to convey } \\
\text { knowledge", "explains well", } \\
\text { "understandable information } \\
\text { presented", "well explained" }\end{array}$ & "explains well" \\
\hline & $\begin{array}{l}\text { Interesting } \\
\text { lecturing }\end{array}$ & $\begin{array}{l}\text { "presented in an interesting } \\
\text { way", "interesting lectures", } \\
\text { "so that it would be interesting } \\
\text { for students, not just lecturers", } \\
\text { "narration, not reading from } \\
\text { slides" }\end{array}$ & \\
\hline & $\begin{array}{l}\text { Qualitative } \\
\text { lecturing }\end{array}$ & "qualitative lecturing" & $\begin{array}{l}\text { "well presented } \\
\text { information" }\end{array}$ \\
\hline & $\begin{array}{l}\text { Pracitcal } \\
\text { teaching } \\
\text { dominates }\end{array}$ & $\begin{array}{l}\text { "loads of practice", "practical } \\
\text { teaching dominates" } \\
\text { "a lot of practice" }\end{array}$ & $\begin{array}{l}\text { "much more practice", } \\
\text { "a lot of practice", "more } \\
\text { of practice than of } \\
\text { theory" }\end{array}$ \\
\hline & $\begin{array}{l}\text { Experience, } \\
\text { knowledge, } \\
\text { skills acquired } \\
\text { not in „university } \\
\text { environment" }\end{array}$ & $\begin{array}{l}\text { "there are exchange } \\
\text { programs", "camps are } \\
\text { organized", "a lot of choices to } \\
\text { participate in various, events", } \\
\text { "activities after lectures", "a lot } \\
\text { of events you can participate } \\
\text { in" ", active events" }\end{array}$ & \\
\hline
\end{tabular}


Table 3. Continuation

\begin{tabular}{|c|c|c|c|}
\hline \multirow[t]{2}{*}{ Category } & \multirow[t]{2}{*}{ Subcategory } & \multicolumn{2}{|c|}{ Supporting statements } \\
\hline & & I course & III-IV courses \\
\hline & $\begin{array}{l}\text { Coherence of } \\
\text { theory and } \\
\text { pracitce }\end{array}$ & $\begin{array}{l}\text { "theory and practice } \\
\text { connected" }\end{array}$ & \\
\hline & $\begin{array}{l}\text { Naming of at- } \\
\text { tributes of qual- } \\
\text { ity study process }\end{array}$ & $\begin{array}{l}\text { "a good teaching", "good } \\
\text { studies", "qualitative } \\
\text { presentations", "you get } \\
\text { useful information", "useful } \\
\text { studies", "motivates students", } \\
\text { "studies encourage } \\
\text { self-improvement", "organize } \\
\text { innovatively", "information } \\
\text { about study possibilities is } \\
\text { presented"','order in the } \\
\text { lectures" }\end{array}$ & $\begin{array}{l}\text { "novelties are applied" } \\
\text { "obtained information is } \\
\text { qualitative and precise" } \\
\text { "personal improve- } \\
\text { ment", "matches the set } \\
\text { standards", "compatible } \\
\text { to European standards", } \\
\text { "specific and expedient", } \\
\text { "according to the } \\
\text { programme" }\end{array}$ \\
\hline & $\begin{array}{l}\text { Appreciation } \\
\text { of personal } \\
\text { achievements }\end{array}$ & $\begin{array}{l}\text { "So that all lecturers would } \\
\text { write a minimum of } 5 \text { " }\end{array}$ & $\begin{array}{l}\text { "assessed according to } \\
\text { physical potential" }\end{array}$ \\
\hline
\end{tabular}

Clear (9), interesting (3) and qualitative (1) lecturing is stressed by first year students of physical education and final year students do not practically connect qualitative studies to lecturing, clarification is mentioned only by two students ("explains well", "presents information well"). We can assume that first year students want to compare studies at higher education school to secondary school model, experience, because in their opinion qualitative studies are when "clearly and precisely presented", "clearly explains", "knows how to convey knowledge", "explains well", "understandable information is presented".

Students, particularly of the first year of studies, disclose conception of qualitative studies connecting it to organizing of study process. It is important for both first (3) and last year students that practical teaching would dominate ("loads of practice", "practical teaching dominates", "a lot of practice"). Cohesion between practice and theory is also mentioned (1) ("theory and practice is connected"). Experience, knowledge and skills acquired in non "university environment" are important for first year students of physical education "there are exchange programs", "camps are organized", "a lot of choiced to participate in various, events", "activities after lectures", "a lot of events you can participate in", "active events"). 
While defining qualitative studies the students of physical education mentioned various aspects of the process of qualitative studies connected to innovation ("novelties are applied", "organize innovatively"), consulting ("information about study possibilities is presented"), management of pedagogical process ("order in the lectures"). First year students stress usefulness of study process (4) ("you get useful information", "useful studies") and also mention "being good", but not clearly define what is "a good teaching", "good studies", "qualitative presentations". Final year students name specific attributes characteristic of qualitative study process, which is expressed by "personal improvement", "matches the set standards", "compatible to European standards", "specific and expedient", "according to the programme".

We can assume that the informants understand that interesting, qualitative and clear lecturing not confined to university environment is necessary in order to achieve good study outcomes. A lot of subjects taught in the programme of physical education at Lithuanian university of Educational Sciences are practical in nature. Students actively participate in sports activities, Lithuanian and international competition. Therefore, assessing quality of studies they stress cohesion of theory and practice and emphasize practical preparation.

Following exterior criteria of assessment area of study process is assessed by validity of requirements for acceptance to studies, validity of applied study methods, and clarity of student achievement assessment system for assessing study outcomes. However, the informants that participated in the research defining the concept of qualitative studies did not name assessment of personal achievement, application of variety of study methods.

\section{The concept of qualitative studies by students of physical education in connection to their lecturers}

The informants defining qualitative studies stressed competence of lecturers, professional experiences, personal traits important for an educator as one of important components (honesty, comprehension, goodness) (Table 4). The students often emphasized competence of lecturers (15) "competent lecturers", "professional", "good specialists", "qualified lecturers", "competent", "demonstrating mastery").

It is important for final year students that lecturers were "good specialists", "having great experience" and first year students mentioned that lecturers have to be simply "good", "understanding".

From the data of our research one can see that future teachers of physical education associate lecturer's activity with qualitative studies. 
Table 4. Subcategories and supporting statements defining category of "Lecturers" in the concept of qualitative studies

\begin{tabular}{|c|c|c|c|}
\hline \multirow[t]{2}{*}{ Category } & \multirow[t]{2}{*}{ Subcategory } & \multicolumn{2}{|c|}{ Supporting statements } \\
\hline & & I course & III-IV courses \\
\hline \multirow[t]{5}{*}{ Lecturers } & Competent & $\begin{array}{l}\text { "competent lecturers", } \\
\text { "professional", "good } \\
\text { specialists", "qualified } \\
\text { lecturers" }\end{array}$ & $\begin{array}{l}\text { "competent", "of high } \\
\text { qualification", "qualified", } \\
\text { "knowing", "demonstrating } \\
\text { mastery", "professionals" }\end{array}$ \\
\hline & Good & "good" & "good specialists" \\
\hline & $\begin{array}{l}\text { Having professional } \\
\text { acknowledgment }\end{array}$ & $\begin{array}{l}\text { "when lecturers are } \\
\text { professors" }\end{array}$ & \\
\hline & $\begin{array}{l}\text { Demonstrating impor- } \\
\text { tant personal qualities } \\
\text { for an educator }\end{array}$ & $\begin{array}{l}\text { "working honestly", } \\
\text { "understanding" }\end{array}$ & "lettered" \\
\hline & $\begin{array}{l}\text { Having professional } \\
\text { experience }\end{array}$ & "experienced" & $\begin{array}{l}\text { "having great experience", } \\
\text { "experienced" }\end{array}$ \\
\hline
\end{tabular}

The concept of qualitative studies by students of physical education in connection to structure of the study programme

The conception of qualitative studies of students in connection to study structure involves two subcategories - subjects of the studies are applied at work and study subjects for preparation of competent specialist. Study subjects for preparation of a competent specialist are important for both first and final year students of physical education ("important subjects for preparation of a good specialist", "selected subjects for a speciality", "the entire study programme is qualitatively made", "content of the subject matches content of professional activity", "necessary subjects"). It is important for final year students (3) that during studies the subjects would be taught that could be directly applied at work ("content of the subject matches content of professional activity", "necessary subjects").

\section{The concept of qualitative studies of students of physical education in connection to material and methodical resources}

Material and methodical resources is a separate area in assessing quality of studies during external evaluation. A few students (9) mentioned importance of material and methodical resources for qualitative studies. Modern teaching base is important for students ("various means", "modern equipment", "having modern-day IT equipment"), and premises are important 
for first year students ("good premises", "good conditions", "enough space in auditorium", "comfortable auditoriums", "when you get a space to sit"). Only two students associated methodical resources ("qualitative methodical material", "clear and exhaustive") with conception of qualitative studies. One has to notice that during external assessment while evaluating quality of studies a lot of attention is paid to find out whether methodical material is enough, if it is accessible, and whether lecturers have prepared methodical material for their presented subject and etc. In the age of information when various technologies are actively used the aspect of methodical material for description of qualitative studies does not look important for students.

\section{The concept of qualitative studies of students of physical education in connection to favorable educational environment}

Some students associate qualitative studies with favorable educational environment (9), because they mention environment that is psychologically comfortable for them ("close and equivalent cooperation", "cooperation between student and lecturer", "student and lecturer understand each other"). Another aspect singled out by the students is not very clearly named, abstract ("all learning conditions are prepared", "when conditions for learning are good", "good conditions"). However, it is still associated with favorable learning conditions.

An insight can be made that students of physical education understand importance of the creation of favorable educational environment for qualitative studies and motivation to study.

\section{The concept of qualitative studies of students of physical education in connection to accessibility of studies and possibility to get employed}

The students associated the concept of qualitative studies with personal interest and accessibility of studies ("when you study what you want", "when you study where you want", "when you like studying", "there are subjects that I want to study"), inexpensive or free of charge studies ("inexpensive", "affordable cost of studies", "you don't have to pay") and employment ("when you can get employed after graduation").

\section{The concept of qualitative studies of students of physical education in connection to prestigeous institutions and studies}

Although this aspect is not emphasized during external assessment, but a few students (5) associate the concept of qualitative studies with prestigious institutions and studies. It is interesting that namely first year students 
emphasized popularity of study programme ("marketable programme", "famous programme") and the fame of the institution of higher education ("famous school").

Therefore, the results of the research reveal a quite thorough conception of the physical education students of Lithuanian university of educational sciences about qualitative studies that are connected to areas which are important performing both interior and exterior assessment of quality of studies.

\section{DISCUSSION}

There has been a discussion going on in the scientific literature for a few decades about the engagement and participation of students in the activity of the academic community and their roles in the activity of studies. Standards and Guidelines for Quality Assurance in the European Higher Education Area [14] also directs towards the participation of students and other stakeholders in the activity of the assurance of the quality of studies. The document emphasizes that it is necessary to guarantee the participation of students in the assurance of the quality of studies. Leišyte and Westerheijden [16], having analyzed the participation of the students of eight European countries in the assurance of the quality of studies in the institutions of higher education, established that the students of all the eight countries are regarded as an important group when assuring the legitimacy of the processes of the assurance of quality. The authors maintain that the real practice of engagement of students and other stakeholders in the work with the quality of studies in the institutions of higher education in these latter years changed, although in some instances students' representation in the assurance of the quality of studies has remained only "symbolic" [16].

Although students are recognized as stakeholders able to influence the quality of studies, nevertheless, it is important to find out what the expectations of students related to quality studies are, how they perceive their role when solving the questions of the procedures of inner assurance of the quality of studies or essential changes of programmes. The research conducted by us revealed that most often students link quality studies to the process of studies, competencies of a university teacher, but their own role and the ability to have influence for the better regarding the quality of studies is not reflected in their perception. The latter statement actualizes the importance of a student engagement and their attitude towards studies. The role of the student in the process of studies depends on his own attitude towards the 
learning at university and the level of his engagement into the activity of the community. In order that the interaction would be more intensive, the effort of a university when activating students to engage into the activity of academic community is needed. Therefore, it is important to analyze and explore in what shape the student enters and in what shape he graduates from his institution of higher education, how his attitude towards studies and their quality changes, how they are linked to the roles perceived and performed by him at his institution of higher education. The research conducted by us in order to revealed the perception of quality studies by the students of the first and second year of studies creates prerequisites to assess the expectations of students and look, while cooperating, for means and ways how to assist students in becoming active participants in the assurance of the quality of studies. The results of the research can help improve the quality of a concrete programme of studies and, thus, it will inseparably have significance for the quality of the studies of an institution as well.

Starkute and Vainevičienè [20] maintain that it is important to analyze not only the role of the student (as of the client and co-creator) in the process of studies, but also to study how it changes. The engagement and participation of students in the process of studies stimulate to identify himself as the member of the academic community and allows the student to have more confidence in himself and realize himself, ipso facto strengthens the sense of responsibility for the results of the performed activity.

The data of our research have highlighted a number of aspects related to the process of studies and the competence of university teachers that are inseparably related to the conception of quality studies by the students. In order that students would achieve the results of the studies, an interesting, quality and clear teaching is necessary, but it is more underlined to the students of the first year of studies. Bobrova et al. [6] investigation that studied the attitude of the students of 1st-4th year of studies of physical training to the quality of studies noticed that, in students' opinion, "the most important advantages or quality of lecturing is the interesting content of lectures and original presentation of it" [6]. The data of these researches reveal the essential aspect of the work of the university teacher when working with students - the quality of teaching. It is not only the content of the studies that has been qualitatively selected, the methods of teaching, systematic process of studies, it is much more - the ability to create interest, pedagogical mastery, counselling when responding to arising questions. These remarks of the students are important and resemble a classic pedagogical truth - the interaction between the educator and the educatee is extremely important 
to the successful educational process. At the present time when information technologies are extremely rapidly implemented in all the areas, including that of education, sometimes the statements are heard that future studies are quality videotaped vizualized lectures without a direct contact with the teacher, however, we would assess it critically, because the principle of pedagogical measure is violated. This research has also revealed that the teacher and his activity are regarded by the majority of the surveyed students as an inseparable component of quality studies. Bobrova et al. [6], who researched the attitude of the students of 1 st-4th year of studies to quality studies also indicate that competence and communicative skills of lecturers are important for students.

We can assume that the students of physical education understand the role of the lecturer as an organizers and leader in the learning process. This observation could be linked to Bobrova et al. [6] research of the students of physical education where it was determined that "assessing studies as multiple phenomenon, the importance of quality determiningfactors students distinguish a role of a lecturer as organizer of learning process and conditions or personal development" [6].

The richness of the library and the sufficiency of its methodological material is an important aspect when assessing the conditions of the implementation of a study programme. However, only two students linked methodological resources to the quality of their studies. A question arises whether the library and its resources are not important for the student. Kardeliene [15], having analyzed the academic library as the space for the competence development of future professionals of physical education, draws the conclusion that in a sense the academic library can be treated as the space for the competence development of the future teachers of physical education. Kardeliene [15], having surveyed 160 students of the first and fourth year of studies at Lithuanian Sports University, noticed that the students who spend more time in the library assess learning environment of the library more favourably, whereas the experiences of the students of the fourth year of studies in the library are more negative than positive, part of them are not satisfied with the quality of new technologies applied in the library either. On the basis of these observations it would be relevant to explore why the students of physical education at Lithuanian University of Educational Sciences almost completely do not link quality studies to the library.

When comparing the findings with the research of all the Lithuanian students, a more mature attitude of the students of physical education towards the structure of their studies has been noticed, because they link the quality 
of studies to the subjects of their studies that are important to their future professional activity, whereas the rest of Lithuanian students link it to their "favourite subjects" [23].

The need for a psychologically comfortable environment mentioned by the students and its linking to the quality of studies would only strengthen the suggestion that the preparation of students for the realities of school life should correspond with a decrease in reality shock and the washout effect [21]. Šeščlienè and Rastauskienè [23] emphasize the training of the abilities of students to adjust to continually changing conditions of social life and activity and cope with them as an important part of the perfection the content of the studies of the preparation of teachers of physical education. It could be thought that this aspect would also be relevant to the students of physical education at Lithuanian University of Educational Sciences since the first year of studies, because the wish of the first year of studies students that they would simply be surrounded by "good" university teachers could suppose their insufficient readiness to adjust to change.

The research of the perception of quality studies by the students is, no doubt, only a prerequisite for the assessment of the attitude of the student towards his studies. Our research included only the students of one speciality - physical education, the future teachers, and it does not reflect the perception of all the students regarding the quality of studies, but it could have a great practical significance when perfecting a concrete study programme in order to get a more comprehensive feedback and actualize the concept of the student as the member of academic community underlining of his engagement and attitude towards studies.

\section{CONCLUSIONS}

1. By analyzing the concept of quality studies of first and final years students of physical education of Lithuanian university of educational sciences eight qualitative categories have been singled out: study outcomes, the structure of study programme, study process, a favorable educational environment, material and methodical resources, lecturers, the accessibility of studies and a possibility to be employed, prestige institutions and studies. Their entirety quite thoroughly reveals areas of assessment of qualitative studies described in European and national documents regulating studies of the institutions of higher education. In most cases, future educators associate qualitative studies with these three areas categories: a 
study process, study outcomes, lecturers. On the other hand, the informants did not name themselves as participants of qualitative study system.

2. The concept of qualitative studies of students of physical education of first and final years does not differ in essence, except that the first year students emphasize clear, interesting, qualitative lecturing and final year students do not associate qualitative studies to lecturing at all. It is important for final year students that the subjects of studies would be directly connected to future work while first year students do not mention this aspect at all.

\section{REFERENCES}

1. Allan A, Pileičikienė N. (2010) Teaching quality assessment in university studies: posibilities for application of student survey. (In Lithuanian). The Quality of Higher Education, 7: 60-87

2. Almadani K, Reid N, Rodrigues S. (2011) Quality assurance: a pressing problem for education in the 21st century. Problems of Education in the 21st Century, 32: $9-22$

3. Aukštosios Mokyklos Veiklos Vertinimo Tvarkos Aprašas. Studijų kokybės vertinimo centro direktoriaus $2010 \mathrm{~m}$. spalio 25 d. İsakymas, Nr. 1-01-135

4. Balasooriya CD, Hugles C, Toohey S. (2009) Impact of a new integrated medicine program on students' approaches to learning. Higher Education Research \& Development, 28: 289-302

5. Baranauskienė I, Bukauskienè V, Valaikienè A. (2011) Assessment of quality assurance in studies of higher education from the students' point of view. (In Lithuanian). Pedagogika, 102: 16-24

6. Bobrova L, Grajauskas L, Alūzas R. (2012) Attitudes of teaching and learning quality: students' assessment context in the university physical education studies. (In Lithuanian). Studies in Modern Society, 3: 30-37

7. Bobrova L, Grajauskas L, Norkus S. (2010) Assessment of quality of university studies of physical education: student's opinion. (In Lithuanian). Teacher Education, 15: 162-176

8. BOLOGNA beyond 2010. Report on the development of the European Higher Education Area, 2010 [accessed 2013-03-01] <http://www.ehea.info/Uploads/ Irina/Bologna\%20beyond\%202010.pdf>

9. Budapest Vienna Declaration on the European Higher Education Area March 12, 2010 [accessed 2012-08-22] <http://www.ond.vlaanderen.be/hogeronderwijs/bologna/documents/declarations_communiques.htm>

10. Communiqué of the Conference of Ministres responsible for Higher Education in Berlin on 19 September 2003 [accessed 2011-04-02] <http://www.ond.vlaanderen.be/hogeronderwijs/bologna/documents/declarations_communiques.htm> 
11. Communique of the Conference of European Ministers Responsible for Higher Education, Bergen, 19-20 May 2005 [accessed 2011-04-02] <http://www.ond. vlaanderen.be/hogeronderwijs/bologna/documents/declarations_communiques.htm>

12. Communiqué of the Conference of European Ministers Responsible for Higher Education, Leuven and Louvain-la-Neuve, 28-29 April 2009 [accessed 201104-02] <http://www.ond.vlaanderen.be/hogeronderwijs/bologna/documents/ declarations_communiques.htm>

13. El Hassan K. (2009) Investigating substantive and consequential validity of student ratings of instruction. Higher Education Research \& Development, 28: 319-333

14. European Association for Quality Assurance in Higher Education (2009). Standards and Guidelines for Quality Assurance in the European Higher Education Area (3th ed). Helsinki: European Association for Quality Assurance in Higher Education

15. Kardelienè L. (2005) Academic library as the space for the development of future physical education professionals' competence. Social Sciences, 3 (49): $104-115$

16. Leišytė L, Westerheijden DF. (2013) Students as stakeholders in quality assurance in eight european countries. (In Lithuanian). The Quality of Higher Education, 10: 20-27

17. Milišiūnaitė I, Butkienė J, Juknytė-Petreikienė I, Keturakis V, Leipaitė D. (2011) Kompetencijų plètotès ir studijų siekinių vertinimo metodikos integravimo ị vidinę studijų kokybės užtikrinimo sistemą rekomendacijos. Vilnius: VU

18. Republic of Lithuania law on Higher Education and Research, 30 April 2009, No. XI-242, Vilnius (As last amended on 24 April 2012 - No. XI-1987)

19. Richards KAR, Templin TJ, Gaudreault KL. (2013) Understanding the realities of school life: recommendations for the preparation of physical education teachers. Quest, 4: 442-457

20. Starkutè, Vainevičienė G. (2013) Is student a university client or a member of academic community? (In Lithuanian). The Quality of Higher Education, 10: $123-150$

21. Studentų Mokymosi Motyvacija, požiūris ị studijų kokybę ir mokestị už studijas, (2008) Mokslo ir studijų stebėsenos ir analizès centras [accessed 2012-08-10] $<$ http://www.mosta.lt/images/documents/analize/tyrimai_ir_ataskaitos/2008/ studentu_\%20poziuris_i_aukstojo_mokslo_sistemos_tobulinima.pdf

22. Studijų programs išorinio vertinimo ir akreditavimo tvarkos aprašas. Lietuvos Respublikos švietimo ir mokslo ministro 2009 m. liepos 24 d. Isakymu Nr. ISAK-1652 (LR ŠMM 2011 m. liepos 29 d. įsakymoNr. V-1487 redakcija)

23. Šeščilienè IM, Rastauskienė GJ. (2008) Lietuvos kūno kultūros akademijos pirmosios pakopos studentų požiūrio ị dėstymo kokybę tyrimas. Švietimo kokybės gerinimas: problemos ir perspektyvos: straipsnių rinkinys [Sudarytojai K. Pukelis ir I. Savickienè]. Kaunas: VDU, 17-28 
24. Westerheijden DF. (2005) Walking towards a moving target: quality as assurance in European higher education. (In Lithuanian). The Quality of Higher Education, 2: 52-71

\section{Correspondence to:}

Sniegina Poteliūnienè $\mathrm{PhD}$

Lithuanian University of Educational Sciences

Studentų 39, LT-08106 Vilnius

Lithuania

sniegina.poteliuniene@leu.lt 